\title{
Nutritional aspects of cognitive impairment
}

\author{
Ivana Đuričić \\ University of Belgrade - Faculty of Pharmacy, Department of Bromatology, \\ Vojvode Stepe 450, 11221, Belgrade, Serbia \\ Corresponding author: Ivana Đuričić, $\mathrm{PhD}$ \\ email: ivana.djuricic@pharmacy.bg.ac.rs
}

\begin{abstract}
Summary
Many scientific arguments in this area, implicate low level of important nutrients in cognitive decline, simultaneously suggesting better nutritional status as an important goal in the management of cognitive aging.

Key nutrients for the protection of cognitive function are B-group vitamins, polyphenols, vitamin $\mathrm{D}$, and omega-3 polyunsaturated fatty acids (PUFAs). The body of scientific evidence widely supports the roles of folic acid and metabolically related B6 and B12 vitamins in protecting cognitive function in old age. High concentrations of polyphenols in dementia therapy showed a significant increase in cerebral blood volume. Although low vitamin D blood levels were associated with a higher risk of developing dementia, vitamin D supplementation alone was not sufficient to improve cognitive outcomes. In relation to the role of omega-3 PUFAs, research findings indicate protective effects in individuals with cognitive decline. The importance of diets and a healthy lifestyle in the prevention of cognitive impairment are extensively accepted. The Mediterranean diet is the most investigated dietary pattern in observational studies. MIND diet (Mediterranean-DASH Intervention for Neurodegenerative Delay) is updated dietary approach of the Mediterranean-DASH diets. Its components are linked to dementia prevention and overall neuroprotection. It is also reported that regular physical activity maintains the brain function improving blood flow and oxygen supply.
\end{abstract}

Keywords: aging, cognition, dementia, nutrients, diet 


\section{Introduction}

In many countries average lifespan is increasing, thus life expectancy actually exceeds 80 years (1). Noncommunicable diseases increase with age such as diabetes, cardiometabolic diseases, neurological and musculoskeletal disorders, therefore the World Health Organization (WHO) outlines a model of healthy aging in its 'World Report on Ageing and Health' (2). The report highlights two primary factors 'intrinsic capacity' and 'functional ability' as the most important considerations of healthy aging. Intrinsic capacity is a term that describes all physical, mental, and psychosocial capacities of an individual at one point in time. Intrinsic capacity varies across the lifespan and presents one aspect of the functioning of a person during growth and development (3). The environmental characteristics are in close interaction with intrinsic capacity and together determine an individual's functional ability. Environmental factors in a different life-stages may influence the maximum intrinsic capacity of tissues and organ systems, affecting later its rate of decline (4). Factors running in earlier life-stages may contribute to the satisfying functional capacity for older people. A holistic approach to healthy aging has primarily focused on lifestyle, physical performance, natural and socio-cultural environment, and nutritional factors rather than the presence and treating disease (5). Diet is a changeable environmental factor that has been associated with protective relations against cognitive impairment. At present, dementia affects about 50 million people and is expected to reach 80 million by 2030 and 150 million by 2050 worldwide. It is verified that cognitive function declines with age, indicating a preclinical silent phase, subjective cognitive decline as a further stage, mild cognitive impairment (MCI), and major neurocognitive impairmentsevere enough to interfere with functional abilities. About $50 \%$ of patients with MCI are predetermined to develop dementia within 5 years (6). Managing risk factors may be an efficient approach in the prevention and treatment of the progressive cognitive decline associated with dementia (7).

Many scientific arguments, derived mostly from observational studies, implicate a low level of important nutrients in cognitive decline, simultaneously suggesting better nutritional status as an important goal in the management of cognitive aging $(8,9)$. Emerging aspects of nutrition research such as individual food components, food groups, and dietary patterns are covered in this Review.

\section{Nutrients related to cognitive functions}

Much research has been focused on the roles of specific nutrients concerning cognition in older age. Increased use of drugs, reduced food intake and compromised nutrient absorption may cause deficiencies of many micro- and macronutrients and consequently complex metabolic changes in older adults. 


\section{B vitamins}

Researchers have been long time interested in the potential connection between B vitamins deficiency and dementia $(10,11)$. Folic acid, vitamins B6, and B12 are required for homocysteine metabolism and even moderately raised homocysteine levels might be related to increased risk of dementia in people older than 65 years (12). Elevated homocysteine levels may impair the brain function by affecting methylation processes, in turn disturbing gene expression in the $\beta$ amyloid pathway and leading to neuronal cell death due to cerebrovascular ischemia (11). It seems that the homocysteine level increases with aging in cerebrospinal fluid, amplifying intracellular and extracellular accumulation of $\beta$ amyloid, therefore causing harmful effects on the endothelial cells of small brain blood vessels (13). Homocysteine is produced by methyl transfer reactions during the metabolism of methionine and its elimination from the body may be performed in two pathways, one of which takes vitamin B6 and the other folate and vitamin B12 (14). Results of a recent meta-analysis confirmed minor effects of vitamin B on preventing cognitive decline (15). Available data certified significant cognitive decline in individuals with high homocysteine levels and B vitamins supplementation were found to improve cognition particularly in this subgroup (12).

\section{Antioxidants}

The brain is most liable to oxidative damage, causing the neuroimmune response to stress, vascular and neuronal disorders, and induction of mechanisms foregoing the onset of cognitive decline. Consumption of potent antioxidants, such as vitamin $\mathrm{C}, \mathrm{E}$, and carotenoids are effective in a struggle with the pathogenesis and progression of dementia (16). The brain has a high ability to maintain homeostasis of vitamin $\mathrm{C}$, particularly during prolonged vitamin $\mathrm{C}$ deficiencies, indicating the importance of the biological role of vitamin $\mathrm{C}$ in central nervous functioning (17). Vitamin $\mathrm{C}$ is a cofactor in numerous processes such as the biosynthesis of tyrosine, carnitine, collagen, peptide hormones, and myelin $(18,19)$. Vitamin $\mathrm{E}$ has varying functions like potent antioxidant and anti-inflammatory properties, showing beneficial effects in the treatment of dementia associated pathology (20). Carotenoids are an important representative of plant pigments, especially those found in dark leafy greens (21). Results of a recent meta-analysis of a few cohort studies have shown borderline significance regarding dietary intake of carotenoids and its protective effect on the risk of dementia. Taking beta-carotene has not confirmed the slowing down of cognitive decline in some longitudinal studies $(22,23)$. A recent study reported a moderate decrease in cognitive decline with higher consumption of lutein+zeaxanthin and total carotenoids, but significant decrease with greater intakes of lycopene (24).

Non-nutrient bioactive compounds, most notably polyphenols and anthocyanins have direct antioxidant features. Essential elements such as zinc, copper, selenium serve 
as cofactors for enzymes and proteins with antioxidative activity. It has been suggested that the pathogenesis and progression of dementia might be mediated by oxidative stress or inappropriate antioxidant defense (25). Polyphenols intake ranging from 200 and 300 $\mathrm{mg}$ per $100 \mathrm{~g}$ of fresh weight is associated with the consumption of fruits such as grapes, berries, and various non-berry fruits (apples, plums, cherries) (26). Additionally, a cup of coffee or tea contains around $100 \mathrm{mg}$ of polyphenols. Chocolate, nuts, legumes, particularly red wine also contribute to the polyphenol intake.

\section{Vitamin D}

Vitamin D plays an important role in the protection of neurons and maintains normal brain functions. Its receptors are present in brain regions involved in cognition. Vitamin D is included in the regulation of immune function, cellular homeostasis, and modulation of synaptic structure (27). Proposed mechanisms for the protective effects of metabolically active 1,25-dihydroxy vitamin D against cognitive decline include antioxidative activity, decreasing ischemia, clearing $\beta$ amyloid peptide, regulating intraneuronal calcium, and choline acetyltransferase neurotrophic factors (28). Although lower vitamin D blood level is associated with a higher risk of developing dementia, it is shown that vitamin D supplementation alone is not sufficient to improve cognition. According to the Vitamin D Council recommendations middle-aged and older adults should have serum vitamin $\mathrm{D}$ level in a range of $70-80 \mathrm{ng} / \mathrm{mL}$ (28).

\section{Polyunsaturated fatty acids (PUFAs)}

Omega 3 PUFAs, especially docosahexaenoic acid (DHA), have an essential role in the central and peripheral nervous system metabolism. DHA is mostly accumulated in the brain and the relation between omega-3 PUFAs intake and brain function is reasonably well accepted. Omega-3 PUFAs play a role in many aspects of brain physiology such as membrane fluidity, synaptic function, inflammation, cerebral blood flow, and neurotrophic effects. Linked to their structural role in neuronal membranes omega-3 PUFAs communicate directly with membrane-bound proteins, transporters, and ion channels, glucose transporters, thus affecting signal transduction and synaptic activity $(29,30)$. Omega-3 PUFAs may impact cerebral blood flow influencing endothelial function (31). They perform powerful antiapoptotic effects and help to maintain healthy neurons and synaptic structures. The very recent review encompasses inconsistent results from large observational studies and clinical trials of omega-3 fatty acids and cognitive function in elderly participants (9). Even though no effect was found in some observational studies, the relationship between higher blood concentrations of omega-3 fatty acids and decreased risk of cognitive decline was confirmed. In one clinical trial, 6 months supplementation with $900 \mathrm{mg} /$ day DHA was linked with improved 'immediate and delayed Verbal Recognition Memory scores' in both genders, age $\geq 55$ (32). In a beneficiary sense, another study found improvement in 
executive function after supplementation with $800 \mathrm{mg}$ docosahexaenoic acid and 225 mg eicosapentaenoic acid a day for 3 years in non-demented older adults with low baseline omega-3 index (33).

\section{Food groups related to cognitive functions}

\section{Fruits and vegetables}

Epidemiological studies based on fruit and vegetable intake and cognition have extensively established that adequate consumption may prevent cognitive impairment, while the low intake has been associated with a higher risk for cognitive decline. In most observational studies benefit were highest for dark leafy greens and berries, good sources of folate, and antioxidants $(34,35)$.

\section{Fish and seafood}

The results of a 2017 meta-analysis supported the potential preventive role of fish and seafood consumption in age-related cognitive decline (36). Slower decline in semantic memory and perceptual speed was found in individuals with habitual consumption of one or more seafood meals compared to those with less than one seafood meal intake (37). The certain genetic background might be a reason for a different response on fish consumption in individuals.

\section{Nuts and olive oil}

Few studies have explored nuts and olive oil intake with cognitive outcomes but not separately, merely in the context of a Mediterranean dietary pattern. JAMA Internal Medicine reported results of a randomized clinical trial that improved cognitive function concerning long-term consumption of the Mediterranean diet with either extra virgin olive oil (1L per week) or nuts (30 g per day) (38).

\section{Dietary patterns and lifestyle habits}

The importance of nutrition and a healthy lifestyle in the prevention of cognitive impairment is widely accepted. Numerous observational studies have reported a generally beneficial effect of sticking to the Mediterranean diet on reducing the risk of MCI, dementia, or overall neurodegenerative diseases (39-41). The Mediterranean diet is the most investigated dietary pattern which is based on a high intake of fruits and vegetables, whole grains, olive oil, legumes and fish instead of red meat, regular consumption of fermented dairy, seeds, nuts, moderate consumption of red wine (4244). The Mediterranean diet emphasizes a high intake of folic acid and other vitamins B, vitamin E, carotenoids, flavonoids, dietary fiber, and monounsaturated fatty acids, a balanced intake of unsaturated and reasonably low intake of saturated fatty acids. Omega-3 fatty acids are highly recommended in the Mediterranean dietary approach 
(42-44). Other dietary patterns have been also taken into consideration for cognitive outcomes. Beneficial associations between cognitive outcomes and adherence to the Dietary Approaches to Stop Hypertension (DASH) diet in both genders have been reported in two observational studies $(45,46)$, whereas one study found no association (47). The DASH diet emphasizes a high intake of fruits, vegetables, whole grains, lean animal protein, and reasonably low consumption of red meat, foods that are low in saturated and trans-fatty acids, sugar, and sodium. This dietary approach is reached in calcium, potassium, magnesium, fiber, and protein intake, but low in saturated and total lipids, cholesterol, and sodium (48). The updated dietary approach called MIND diet (Mediterranean-DASH Intervention for Neurodegenerative Delay) is a hybrid of the Mediterranean-DASH diets. Its components are linked to dementia prevention and overall neuroprotection. The MIND diet score emphasizes natural foods originated by plants and limited intakes of animal foods. It authentically specifies consumption of berries and green leafy vegetables, but not high fruit consumption like in the Mediterranean and DASH diets (3-4 servings per day) high dairy (more than 2 servings per day in DASH), high potato consumption (2 servings per day in the Mediterranean) or more than 1 fish meal per week (in the Mediterranean diet recommendation may reach greater than 6 meals per week) (49). The MIND diet approach was related to a lower risk of Alzheimer's disease and a slower decline in cognitive outcome in four observational studies $(47,49-51)$.

Besides, the health condition depends on numerous aspects of lifestyle habits. At the same time, education about nutrition and physical activity is crucial for cognitive function. The importance of regular physical activity should be pointed out to individuals with cognitive disorders. It is advisable to exercise 2 or 3 times a week for more than $60 \mathrm{~min}$ in order to improve physical performance. The exercise should be supervised by professional guide (52). It is also reported that regular physical activity maintains the brain function improving blood flow and oxygen supply. Consequently, the danger of Alzhemier's type dementia might be decreased (53).

Having in mind the complexity of biological interactions between various components of the diet, the whole diet approach should be in the focus of further investigations rather than individual nutrients or food groups. Such an investigation would enable better understanding of the nutrition role in chronic diseases like agerelated cognitive impairment. 


\section{References}

1. Organization WH. Global health observatory (GHO) data. Life expectancy. World Health Organization, Geneva Available:

http://www whoint/gho/mortality_burden_disease/life_tables/situation_trends_text/en/Accessed. 2016;20

2. Organization WH. World report on ageing and health: World Health Organization; 2015.

3. Beard JR, Officer A, De Carvalho IA, Sadana R, Pot AM, Michel J-P, et al. The World report on ageing and health: a policy framework for healthy ageing. The Lancet. 2016;387(10033):2145-54 .

4. Ben-Shlomo Y, Cooper R, Kuh D. The last two decades of life course epidemiology, and its relevance for research on ageing. International Journal of Epidemiology. 2016;45(4):973-88.

5. Calder P, Carding S, Christopher G, Kuh D, Langley-Evans S, McNulty H. A holistic approach to healthy ageing: how can people live longer, healthier lives? Journal of Human Nutrition and Dietetics. 2018;31(4):439-50.

6. Gauthier S, Reisberg B, Zaudig M, Petersen RC, Ritchie K, Broich K, et al. Mild cognitive impairment. The Lancet. 2006;367(9518):1262-70.

7. Jiang T, Yu J-T, Tian Y, Tan L. Epidemiology and etiology of Alzheimer's disease: from genetic to non-genetic factors. Current Alzheimer Research. 2013;10(8):852-67.

8. Moore K, Hughes CF, Ward M, Hoey L, McNulty H. Diet, nutrition and the ageing brain: current evidence and new directions. Proceedings of the Nutrition Society. 2018;77(2):152-63.

9. Scarmeas N, Anastasiou CA, Yannakoulia M. Nutrition and prevention of cognitive impairment. The Lancet Neurology. 2018;17(11):1006-15.

10. Lefèvre-Arbogast S, Féart C, Dartigues J-F, Helmer C, Letenneur L, Samieri C. Dietary B vitamins and a 10-year risk of dementia in older persons. Nutrients. 2016;8(12):761.

11. Smith AD, Refsum H. Homocysteine, B Vitamins, and Cognitive Impairment. Annual Review of Nutrition. 2016 Jul 17;36:211-39. PubMed PMID: 27431367. Epub 2016/07/20. eng.

12. Smith AD, Refsum H, Bottiglieri T, Fenech M, Hooshmand B, McCaddon A, et al. Homocysteine and dementia: an international consensus statement. J Alzheimers Dis. 2018; 62: $561-70$.

13. Moretti R, Caruso P. The controversial role of homocysteine in neurology: from labs to clinical practice. International Journal of Molecular Sciences. 2019; 20 (1): 231.

14. Kumar A, Palfrey HA, Pathak R, Kadowitz PJ, Gettys TW, Murthy SN. The metabolism and significance of homocysteine in nutrition and health. Nutr Metab. 2017; 14: 78.

15. McCleery J, Abraham RP, Denton DA, Rutjes AW, Chong LY, Al-Assaf AS, et al. Vitamin and mineral supplementation for preventing dementia or delaying cognitive decline in people with mild cognitive impairment. Cochrane Database of Systematic Reviews. 2018 (11).

16. Freitas HR, Ferreira GdC, Trevenzoli IH, Oliveira KdJ, de Melo Reis RA. Fatty acids, antioxidants and physical activity in brain aging. Nutrients. 2017;9(11):1263.

17. Travica N, Ried K, Sali A, Scholey A, Hudson I, Pipingas A. Vitamin C status and cognitive function: a systematic review. Nutrients. 2017;9(9):960. 
18. Kocot J, Luchowska-Kocot D, Kiełczykowska M, Musik I, Kurzepa J. Does vitamin C influence neurodegenerative diseases and psychiatric disorders? Nutrients. 2017;9(7):659.

19. Eldridge CF, Bunge MB, Bunge RP, Wood PM. Differentiation of axon-related Schwann cells in vitro. I. Ascorbic acid regulates basal lamina assembly and myelin formation. The Journal of Cell Biology. 1987;105(2):1023-34.

20. Browne D, McGuinness B, Woodside JV, McKay GJ. Vitamin E and Alzheimer's disease: what do we know so far? Clinical Interventions in Aging. 2019;14:1303.

21. Hammond BR, Jr, Renzi LM. Carotenoids. Advances in Nutrition. 2013;4(4):474-6.

22. Crichton GE, Bryan J, Murphy KJ. Dietary antioxidants, cognitive function and dementia-a systematic review. Plant Foods for Human Nutrition. 2013;68(3):279-92.

23. Li F-J, Shen L, Ji H-F. Dietary intakes of vitamin E, vitamin C, and $\beta$-carotene and risk of Alzheimer's disease: a meta-analysis. Journal of Alzheimer's Disease. 2012;31(2):253-8.

24. Devore EE, Kang JH, Stampfer MJ, Grodstein F. The association of antioxidants and cognition in the Nurses' Health Study. American Journal of Epidemiology. 2013;177(1):33-41.

25. Mecocci P, Boccardi V, Cecchetti R, Bastiani P, Scamosci M, Ruggiero C, et al. A long journey into aging, brain aging, and Alzheimer's disease following the oxidative stress tracks. J Alzheimers Dis. 2018; 62: 1319-35.

26. Llorach R, Garcia-Aloy M, Tulipani S, Vazquez-Fresno R, Andres-Lacueva C. Nutrimetabolomic strategies to develop new biomarkers of intake and health effects. Journal of Agricultural and Food Chemistry. 2012;60(36):8797-808.

27. Anjum I, Jaffery SS, Fayyaz M, Samoo Z, Anjum S. The role of vitamin D in brain health: a mini literature review. Cureus. 2018;10(7).

28. Bruins MJ, Van Dael P, Eggersdorfer $M$. The role of nutrients in reducing the risk for noncommunicable diseases during aging. Nutrients. 2019;11(1):85.

29. Dyall SC. Long-chain omega-3 fatty acids and the brain: a review of the independent and shared effects of EPA, DPA and DHA. Frontiers in Aging Neuroscience. 2015;7:52.

30. Innis SM. Dietary (n-3) fatty acids and brain development. The Journal of Nutrition. 2007;137(4):855-9.

31. Wang Q, Liang X, Wang L, Lu X, Huang J, Cao J, et al. Effect of omega-3 fatty acids supplementation on endothelial function: a meta-analysis of randomized controlled trials. Atherosclerosis. 2012;221(2):536-43.

32. Yurko-Mauro K, McCarthy D, Rom D, Nelson EB, Ryan AS, Blackwell A, et al. Beneficial effects of docosahexaenoic acid on cognition in age-related cognitive decline. Alzheimers Dement. 2010; 6: 456-64.

33. Hooper C, De Souto Barreto P, Coley N, Cantet C, Cesari M, Andrieu S, et al. Cognitive changes with omega-3 polyunsaturated fatty acids in non-demented older adults with low omega-3 index. J Nutr Health Aging. 2017; 21: 988-93.

34. Morris MC, Wang Y, Barnes LL, Bennett DA, Dawson-Hughes B, Booth SL. Nutrients and bioactives in green leafy vegetables and cognitive decline: Prospective study. Neurology. 2018;90(3):e214-e22. 
35. Devore EE, Kang JH, Breteler MM, Grodstein F. Dietary intakes of berries and flavonoids in relation to cognitive decline. Annals of Neurology. 2012;72(1):135-43.

36. Samieri C, Morris M-C, Bennett DA, Berr C, Amouyel P, Dartigues J-F, et al. Fish intake, genetic predisposition to Alzheimer disease, and decline in global cognition and memory in 5 cohorts of older persons. American Journal of Epidemiology. 2018;187(5):933-40.

37. van de Rest O, Wang Y, Barnes LL, Tangney C, Bennett DA, Morris MC. APOE $\varepsilon 4$ and the associations of seafood and long-chain omega-3 fatty acids with cognitive decline. Neurology. 2016;86(22):2063-70.

38. Valls-Pedret C, Sala-Vila A, Serra-Mir M, Corella D, De la Torre R, Martínez-González MÁ, et al. Mediterranean diet and age-related cognitive decline: a randomized clinical trial. JAMA Internal Medicine. 2015;175(7):1094-103.

39. Psaltopoulou T, Sergentanis TN, Panagiotakos DB, Sergentanis IN, Kosti R, Scarmeas N. Mediterranean diet, stroke, cognitive impairment, and depression: a meta-analysis. Annals of Neurology. 2013;74(4):580-91.

40. Sofi F, Abbate R, Gensini GF, Casini A. Accruing evidence on benefits of adherence to the Mediterranean diet on health: an updated systematic review and meta-analysis. The American Journal of Clinical Nutrition. 2010;92(5):1189-96.

41. Singh B, Parsaik AK, Mielke MM, Erwin PJ, Knopman DS, Petersen RC, et al. Association of mediterranean diet with mild cognitive impairment and Alzheimer's disease: a systematic review and meta-analysis. Journal of Alzheimer's Disease. 2014;39(2):271-82.

42. Bach-Faig A, Berry EM, Lairon D, Reguant J, Trichopoulou A, Dernini S, et al. Mediterranean diet pyramid today. Science and cultural updates. Public Health Nutrition. 2011;14(12A):2274-84.

43. Yannakoulia M, Kontogianni M, Scarmeas N. Cognitive health and Mediterranean diet: just diet or lifestyle pattern? Ageing Research Reviews. 2015;20:74-8.

44. Boccardi V, Calvani R, Limongi F, Marseglia A, Mason A, Noale M, et al. Consensus paper on the "executive summary of the international conference on Mediterranean diet and health: a lifelong approach" an Italian initiative supported by the Mediterranean Diet Foundation and the Menarini Foundation. Nutrition. 2018;51:38-45.

45. Zhu N, Jacobs DR, Meyer K, He K, Launer L, Reis J, et al. Cognitive function in a middle aged cohort is related to higher quality dietary pattern 5 and 25 years earlier: the CARDIA study. The Journal of Nutrition, Health \& Aging. 2015;19(1):33-8.

46. Smyth A, Dehghan M, O'Donnell M, Anderson C, Teo K, Gao P, et al. Healthy eating and reduced risk of cognitive decline: A cohort from 40 countries. Neurology. 2015;84(22):2258-65.

47. Shakersain B, Rizzuto D, Larsson SC, Faxén-Irving G, Fratiglioni L, Xu W-L. The Nordic prudent diet reduces risk of cognitive decline in the Swedish older adults: a population-based cohort study. Nutrients. 2018;10(2):229.

48. Appel LJ, Moore TJ, Obarzanek E, Vollmer WM, Svetkey LP, Sacks FM, et al. A clinical trial of the effects of dietary patterns on blood pressure. New England Journal of Medicine. 1997;336(16):1117-24. 
49. Morris MC, Tangney CC, Wang Y, Sacks FM, Bennett DA, Aggarwal NT. MIND diet associated with reduced incidence of Alzheimer's disease. Alzheimer's \& Dementia. 2015;11(9):1007-14.

50. Morris MC, Tangney CC, Wang Y, Sacks FM, Barnes LL, Bennett DA, et al. MIND diet slows cognitive decline with aging. Alzheimer's \& Dementia. 2015;11(9):1015-22.

51. Berendsen AM, Kang JH, Feskens EJ, de Groot C, Grodstein F, van de Rest O. Association of long-term adherence to the mind diet with cognitive function and cognitive decline in American women. The Journal of Nutrition, Health \& Aging. 2018;22(2):222-9.

52. Lam FM, Huang M-Z, Liao L-R, Chung RC, Kwok TC, Pang MY. Physical exercise improves strength, balance, mobility, and endurance in people with cognitive impairment and dementia: a systematic review. Journal of Physiotherapy. 2018;64(1):4-15.

53. Larson EB, Wang L, Bowen JD, McCormick WC, Teri L, Crane P, et al. Exercise is associated with reduced risk for incident dementia among persons 65 years of age and older. Annals of Internal Medicine. 2006;144(2):73-81. 


\title{
Nutritivni aspekti poremećaja kognitivnih funkcija
}

\author{
Ivana Đuričić \\ Univerzitet u Beogradu - Farmaceutski fakultet, Katedra za Bromatologiju, \\ Vojvode Stepe 450, 11221, Beograd, Srbija
}

Autor za korespondenciju: ivana.djuricic@pharmacy.bg.ac.rs

\section{Kratak sadržaj}

Novi naučni dokazi u ovoj oblasti ukazuju na nedostatke određenih hranljivih materija u opadanju kognitivnih funkcija, istovremeno pokazujući da bolji nutritivni status može biti važan u očuvanju kognicije kod starijih osoba.

Ključni nutrijenti za zaštitu kognitivnih funkcija su vitamini B grupe, polifenoli, vitamin D i omega-3 polinezasićene masne kiseline (PMK). Sveukupnost naučnih dokaza u ovom trenutku najjače podržava uloge folata i metabolički povezanih vitamina B6 i B12 u zaštiti kognitivnih funkcija u starijoj životnoj dobi. Visoke koncentracije polifenola u terapiji demencije pokazale su značajno povećanje volumena cerebralne krvi. Iako su niže koncentracije vitamina $\mathrm{D}$ u serumu bile povezane sa većim rizikom za razvoj demencije, suplementacija vitaminom D nije bila dovoljna za poboljšanje kognitivnih ishoda. U vezi sa ulogom omega-3 PMK, rezultati istraživanja ukazuju na zaštitne efekte kod osoba sa kognitivnim smetnjama. Dijetarni režim i zdrav stil života igraju značajnu ulogu u prevenciji kognitivnih poremećaja. Mediteranska ishrana je najčešće ispitivani dijetarni obrazac u observacionim studijama. Pokazano je da je koncept MIND dijete (Mediterranean-DASH Intervention for Neurodegenerative Delay) u vezi sa neuroprotektivnim efektima i prevencijom demencije. Redovna fizička aktivnost predstavlja značajnu komponentu zdravog životnog stila u održanju vitalnosti moždanih funkcija.

Ključne reči: starenje, kognicija, demencija, nutrijenti, dijeta 